\title{
The Use of Taboo Words in Bad Boys II Movie
}

\author{
Ayu Asmidah \\ Balikpapan University \\ asmidah_ayu@yahoo.co.id \\ Jepri \\ Balikpapan University \\ jeprinainggolan@gmail.com

\section{Rosmiati} \\ Balikpapan University \\ rosmiati@uniba-bpn.ac.id
}

\begin{abstract}
:
This research aims to analyze taboo words in Bad Boys II movie. The objective of this research is to identify the types of taboo words that are mostly found in the movie. The theory used in this research is Sociolinguistics by Wardhaugh, specifically types of taboo words. The methodology employed is qualitative approach with the researcher as the main instrument to collect the data in forms of dialogue from the movie by watching it repeatedly. The researcher analyzes and interprets the data based on the taboo words and its functions proposed by Wardhaugh. The findings of the research are dominated by bodily functions; followed by religious matters, and certain game animals, and they are aimed to provoke chaotic reaction.
\end{abstract}

Keywords: taboo words, Bad Boys II

\section{INTRODUCTION}

Taboo words are always associated with inappropriate language and it cannot be used in daily conversations. Therefore, taboo words are still considered as offensive and savage words in most languages, such as English. Taboo is a wide phenomenon across the world, and it has become sensitive that the word "taboo" itself is a taboo. Words or sentences, even some topics have, at the moment, become so sensitive to talk about that they have become taboo. According to Wardhaugh (2010, p.249), taboo is "the prohibition or 
avoidance in any society of behavior believed to be harmful to its members in that it would cause them anxiety, embarrassment, or shame. It is an extremely strong politeness constraint. Consequently, so far as language concerned, certain things are not to be said or certain objects can be referred to only in certain circumstances." The use of taboo words such as "fuck" and "cunt" would lead to prosecution and imprisonment so that they were not used in printed media such as newspaper. However, it seems that nowadays the attitude towards the function of taboo words has already changed. The changes happened because the legal sanctions were disappearing and there are tendencies that now people are getting more relaxed to accept taboo words. As a result, taboo words are now commonly found when someone expresses the uncontrolled anger and emotive feeling.

The reason of the researcher chooses taboo words as the problem of this research because taboo words is interesting linguistic research, the problem may happen through a movie which is a representation of human life in society. Therefore, people need to understand the types and the taboo words provoke chaotic reaction or express the un-control anger.

The researcher uses a movie entitled Bad Boys II directed by Michael Bay as the object of the research. This movie is an American action movie. This movie is very interesting to be analyzed, because the characters in the story applied a communication style using taboo words. They usually use taboo words when the police officers are on duty of detecting and solving the narcotics cases. The police officers also call their partners with taboo words which helps them hide their identity as police officers for they usually use the appropriate and formal language. Bad Boys II is chosen as the object of the research because the conversations of the characters style using taboo words when they are on duty of detecting the narcotics cases. In this research, the researcher focuses on the discussion of the types of taboo words which are employed by the characters, and the taboo words provoke chaotic reaction or express the uncontrolled anger from the characters in the movie. Through this movie, taboo words uttered in the movie is a common thing and shows that taboo still exists around us. Therefore, people believe it as the reality of phenomenon. The objectives of this research is to identify the types of taboo words in the Bad Boys II.

\section{LITERATURE REVIEW}

Language is an essential in human life. People need language as a tool to interact each other in society to express their ideas and their feelings. Without language, people will experience difficulties to do their activity in their daily life. A study focuses on language and society called sociolinguistics. According to Wardhaugh (2006, p.13), sociolinguistics is concerned with investigating the relationship between language and society with the goal being a better understanding of the structure of language and how language function in communication. Hudson (1980, p.4) states that sociolinguistics is also the study of effects of all various aspects to society, including cultures, norms, and contexts on the language us used.

Taboo is one of scientific phenomenon, which is interesting to be discussed, every society has its own way to express the taboo. Wardhaugh (2006, p.230) states that "linguistics 
taboo violated on occasion to draw attention to oneself, to show contempt, to be chaotic reaction or uncontrolled, or to mock authority". The penalty of breaking a linguistics taboo can be served for blasphemy and obscenity is still crimes in many jurisdictions. In additions, the degree of violating the taboo is bigger among close or intimate relationship of breakers. In this research, the researcher focuses chaotic reaction or uncontrolled anger express in Wardhaugh as the main goal to be achieved in this research suggested by Wardhaugh in Bad Boys II.

\section{Types of Taboo Words}

In classifying types of taboo words, some sociolinguistics have classified taboo words into several types. Wardhaugh (2006) divides taboo words into eight types based on the meaning. They are:

1. One's Mother in-Law; this term is used to describe a woman who has an affair with many partners, such as "motherfucker" and "slut".

2. Certain game animals; this term is related to animal's, the behavior of animal's, such as "bitch", "bull", and "dog".

3. Sex; this term refers to sexual such as, "fuck".

4. Death; this term refers to something that people fear to face, such as "go to hell".

5. Excretion; this term is connected to human excretion, such as "shit" or "piss".

6. Bodily functions; these terms are related to human's body or human's genitals, such as "motherfucker", "cunt", "cock", "butthole", "ass", "tities" and "pussy".

7. Religious matters; these terms are related to God, such as "Gosh!", "Dolly!", "Motherfucker" referring to God. "Gee! Jinggo! Jeez!" referring to Jesus, "Hell”, "Jesus Christ" or "Goddamn you" based on religious matters which means the religious is behaving outside the customs of religious belief and being ignorant of the guidelines of particular religious order.

8. The left hand; this term refers to the symbol of sexual intercourse by showing the middle finger of the left hand, such as "fuck you", or "screw you".

\section{Function of Taboo Words}

The researcher employs a theory from Wardhaugh to see the function of uttering taboo words. Taboo words are usually uttered because there is a reason behind them. According to Wardhaugh (2006, p.239), taboo is disregarded in particular occasion because they have several functions such as to draw attention to oneself, to show contempt, to show chaotic reaction or uncontrolled anger express, and to mock authority. To give a clear explanation of the functions of taboo words, below are brief descriptions of the functions.

\section{To Draw Attention to Oneself}

People utter taboo word in order to get attention from listener from time to time, especially when people do not award to conversation. Powerful language's connotation can stimulate 
an instant reaction from the audience, for example saying something like "hey you son of a bitch!".

\section{To Show Contempt}

The use of taboo words in conversation between two people can also mean to show contempt. Contempt means the impression in which a person or may be something is totally useless and cannot be regarded. In order words, when someone tries to show contempt by using taboo words, he or she will insult in the addressee by uttering words that can offend their pride.

\section{To Show Chaotic Reaction}

When someone utters taboo words, he or she has an intention to provoke certain response such as violation or anger from others. Verbal obscenity can be the most efficient symbolic offered to protester intended for inviting chaotic reaction or uncontrolled anger expression. Taboo words are considered successful when the response is suitable with the speaker's expectation.

\section{To Mock Authority}

Sometimes people use taboo words then they are not satisfied with public images such as government and institutions, asserts that verbal obscenity communicates a significant hatred for society's rule, a rebellion against power as well as impertinence for things that are considered sacred. In order words, people used taboo words because they want to express their disappointment about reality that is different from what they have expected. Therefore, some people may prefer to use certain taboo words that are directed to mock authority in order to show their disbelief about things related to the government.

\section{RESEARCH METHODOLOGY}

In this research, the researcher uses qualitative research. This research is called qualitative research since this research presents the descriptive data, in forms of words, spoken or written by people. There are two classified sources of data in which the researcher devices the data. The first is primary data. The primary data is the main object that the researcher uses in this analysis. The primary data are taken from Bad Boys II.

The researcher chooses the movie, because the conversations of the characters style using taboo words when they are on duty of detecting the narcotics cases. In this research, the researcher focuses on the discussion of the types of taboo words which are employed by the characters, and the taboo words provoke chaotic reaction or express the uncontrolled anger from the characters in the Bad Boys II. Through this movie, taboo words uttered in the movie is a common thing and shows that taboo still exists around us. Therefore, people believe it as the reality of phenomenon. The secondary data are the support of the primary data. It is supporting references, such as a book, journal, web and article. In this analysis, the researcher focuses on the sociolinguistic approach. In collection the data, the researcher does several steps. The aim is to know the types of taboo words which are employed by the 
characters, and the taboo words provoke chaotic reaction or express the uncontrolled anger from the characters in the Bad Boys II. There are several methods for qualitative research. First, the researcher watches that movie and observes the conversation in the movie. Second, the researcher identifies the types of taboo words based on the movie. Third, because the form of main data is audio, the researcher needs to listen slowly.

\section{FINDINGS AND DISCUSSIONS}

There are three types of taboo words produced by the characters in Bad Boys II. They are bodily functions, certain game animals, and religious matters. These findings are to be explained as follows:

\section{Bodily Functions}

The first type of taboo words found in Bad Boys II is bodily functions. Bodily functions become the most dominant type used by the characters in the movie. Bodily functions is described as humans bodily genitals, for example, "motherfucker", "cock", "butthole", "cunt", "ass", "tities" and "pussy".

Mike: "That one puckered up my butthole."

Marcus: "Almost fucking crushed my head."

Screeenplay (00.36.14 - 00.36.17)

The word "butthole" is exteriorized as bodily functions since it is referred to human's body part. The word my butthole means an expression when the character is almost shot to dead. The dialogue between Mike and Marcus above happens in the scene when they are in a gun war with the Haitian Blondy. It is considered bodily functions because it has common or ordinary sense as it means, as human genitals.

\section{Religious Matters}

The second type of taboo words found in Bad Boys II is religious matters. This refers to the taboo words related with behaving outside the customs of religious belief and being ignorant of the guidelines of particular religious order. Religious matters taboo words are, for example, “Christ”, "Jesus”, “God”, “Goddamn", "Hell”, “Jesus Christ".

Marcus: "I'm trying to talk to you. Get the fuck off me, Mike!!!"

Mike: "What the hell is your problem, man?! Why you acting so stupid."

Screeenplay (01.20.40 - 01.20.44)

The dialogue shows the conversation between Marcus and Mike about Mike dating Syd, Marcus's sister. It causes Marcus to create chaotic reaction or uncontrolled anger at Mike. The phrase "what the hell" belongs to the religious matters because hell is a common belief related to religion. 


\section{Certain Game Animal's}

The third type of taboo words found in Bad Boys II is certain game animals. Certain game animals, or any taboo words related to animals or the behavior of animals. It occurs three times. In Bad Boys II, certain game animals are shown in words like "bitch", "bull", and "dog".

Mike: "Why don't you bring it to me real. What is your problem with this?"

Marcus: "You know what? You a dog man."

Screenplay (01.20.55)

In the quotation above "dog" does not mean the actual four-legged animal, but an expression of anger because Marcus feels upset towards Mike. Marcus utters the taboo word, that is "dog". It refers to the behavior of a person who is considered to be shameless and possess dog's impolite nature. It is considered very rude if humans are compared to an animal.

As explained previously, there are three types of taboo words found in the movie. They are expressed in the forms of bodily functions, religious matters, and certain game. According to the analysis of the function, it can be seen that these taboo words are used by the characters in the movie to provoke chaotic reactions. Meanwhile, the rest of the functions (i.e., to draw attention to oneself, to show contempt and to mock authority) has yet to be found in the movie.

\section{CONCLUSION}

After conducting the research, the researcher concludes that the movie contains some taboo words. These taboo words are presented in three types. They are bodily functions, religious matters and certain game animals. These taboo words are uttered to perform a specific function. That function is to provoke chaotic reaction. Taboo words are often produced to perform different types of functions, including to draw attention to oneself, to show contempt and to mock authority. However, the movie has no example of the characters performing dialogues using the taboo words to perform the other functions other than to provoke chaotic reaction.

\section{References}

Anggita, F. N. (2015). A Sociolinguistic Analysis of Taboo Words in Bad Teacher Movie. Yogyakarta: English Language and Literature Study Program Faculty of Languages and Arts Yogyakarta State University.

Bad Boys II Full Movie Script. 
Prologue: Journal on Language and Literature Vol.7 No.2 (2021)

http://movietranscript.blogspot.com/2015/11/2003-bad-boys-ii. Retrieved on February 10th, 2019.

Bogdan, R. C. and Bliken, S. K. (1982) Qualitative Research for Education. Oxford: Oxford University Press.

Bordwell, D. and Thompson, K. (1997) Film Art: An Introduction, 2nd edition. Boston, MA: McGraw-Hill Inc.

Brewer, J. D. (2003) Qualitative Research, in: R.L Miller \& J.D Brewer (Eds.), the A-Z of Social Research: a dictionary of key social science research concepts. (pp.238-241). Thousand Oaks: Sage.

Chaika, E. (1982) Language: The Social Mirror. USA: Newburry House Publisher.

Denzin, N. K. (1978). The Research Act A Theoretical Introduction to Sociological Methods. USA: McGraw-Hill, Inc.

Febrianuswantoro, Y. \& Iragiliati, E. (2012). The Use of Taboo Words Between Main Characters Seen in Bad Boys II movie. Journal. Malang.

Glass, G.V., \& Hopkins, K.D. (1984). Moral Maturity: Measuring the Development of Sociomoral Reasoning Hisdale, N.J: Lawrence Erlbaum Associates.

Hudson, R. A. (1980) Sociolinguistics. New York: Cambridge University Press.

Klarer, M. (2004). An Introduction to Literary Studies (Second Edition). English: Routledge.

Lewis, C. S. (1963) The Worlds Last Nights. Belfast, Ireland.

Putra, W. A. (2016) Taboo Words in Jackass Movie. Yogyakarta: English Department, State Islamic University Sunan Kalijaga.

Radcliffe-Brown, A. (1939) Taboo. Cambridge: Cambridge University Press.

Trudgill \& Andersson, (1990) Bad Language. Basil Blackwell Ltd: UK.

Trudgill \& Anderson. (2000) Sociolinguistic: An Introduction to Language and Society fourth edition. London.

Thomas (1995) Meaning in Interaction: an Introduction to Literary. England: Logman.

Wardhaugh, R. (2006) An Introduction to sociolinguistics. Oxford: Blackwell. . (2010) An Introduction to Sociolinguistics. Sussex: Wiley Blackwell Publishing.

Wellek \& Warren. (1990) Literary Theory. Jakarta: Jaya Library. . (1997) Theory of Literature. New York: Harcourt, Brace. 